\title{
The first case series of Chinese patients in Hong Kong with familial Alzheimer's disease compared with those with biomarker-confirmed sporadic late-onset Alzheimer's disease
}

\author{
YF Shea *, LW Chu, SC Lee, Angel OK Chan
}

\section{A B S T R A C T}

Introduction: Patients with familial Alzheimer's disease are being increasingly reported in Hong Kong. The objectives of this study were to report the clinical features of these patients, and to compare them with those with biomarker-confirmed sporadic late-onset Alzheimer's disease.

Methods: All symptomatic Chinese patients with familial Alzheimer's disease who attended Queen Mary Hospital, Memory Clinic between January 1998 and December 2016 were included. Information about clinical features, baseline Mini-Mental State Examination score, and presenting cognitive symptoms or atypical clinical features were collected. Their clinical features were compared with those of 12 patients with sporadic late-onset Alzheimer's disease with cerebrospinal fluid biomarker evidence of Alzheimer's disease and 14 patients with lateonset Alzheimer's disease and positive amyloid loading on Pittsburgh compound B imaging.

Results: There were three families with familial Alzheimer's disease among whom eight family members were affected. The mean $( \pm$ standard deviation) age of onset and the Mini-Mental State Examination score were $48.4 \pm 7.7$ years and 7.9 \pm 9.2 , respectively. Compared with the sporadic late-onset Alzheimer's disease patients, those with

This article was published on 10 Nov 2017 at www.hkmj.org. familial Alzheimer's disease had an earlier age of onset and presentation (both $\mathrm{P}<0.001$ ) and received the correct diagnosis later (median [interquartile

range], 7.5 [5.3-14.5] vs 2 [1.0-3.3] years; $\mathrm{P}<0.001)$. Patients with familial disease had a lower MiniMental State Examination score at presentation than those having late-onset Alzheimer's disease (mean, $7.9 \pm 9.2$ vs $17.6 \pm 7.2 ; \mathrm{P}=0.01$ ). They also had fewer delusions, and less dysphoria and irritability $(0 \%$ vs $41.7 \%, 0 \%$ vs $50 \%$ and $0 \%$ vs $54.2 \% ; \mathrm{P}=0.04,0.01$ and 0.01 , respectively). There was a trend of less frequent amnesia among patients with familial Alzheimer's disease compared with those having late-onset Alzheimer's disease ( $75 \%$ vs $100 \%$; $\mathrm{P}=0.05)$.

Conclusion: Clinical features differ for patients with familial Alzheimer's disease compared with those with late-onset Alzheimer's disease. There is a delay in diagnosis. Promotion of public awareness of familial Alzheimer's disease is much needed.

\section{Hong Kong Med J 2017;23:579-85}

DOI: $10.12809 / \mathrm{hkmj} 176845$

${ }^{1}$ YF Shea *, MRCP (UK), FHKAM (Medicine)

${ }^{1}$ LW Chu, MD, FRCP (Lond)

${ }^{1} \mathrm{SC}$ Lee, BHS(Nursing)

AOK Chan, MD, FRCPA

Division of Geriatric Medicine, Department of Medicine, LKS Faculty of Medicine, The University of Hong Kong, Queen Mary Hospital, Pokfulam, Hong Kong

Division of Clinical Biochemistry, Department of Pathology \& Clinical Biochemistry, Queen Mary Hospital, Pokfulam, Hong Kong

* Corresponding author: elphashea@gmail.com

New knowledge added by this stud

- There is a significant delay in the diagnosis of familial Alzheimer's disease (FAD) in Hong Kong.

- Patients with FAD had fewer delusions and less dysphoria and irritability compared with patients with sporadic late-onset Alzheimer's disease.

Implications for clinical practice or policy

Promotion of public awareness of FAD is much needed.

\section{Introduction}

Alzheimer's disease (AD) is the most common cause of dementia. It is frequently classified as early-onset $\mathrm{AD}$ (EOAD) if onset is before the age of 65 years and thereafter as late-onset AD (LOAD). Familial AD (FAD) is a special form of EOAD with an autosomal dominant inheritance, and can be caused by mutations in presenilin (PSEN) 1 or 2 and amyloid precursor protein $(A P P)$ genes. Not all patients with EOAD have autosomal dominant FAD, which accounts for less than $1 \%$ of all AD. ${ }^{1}$ The first patient diagnosed with AD by Alois Alzheimer was called Auguste Deter; she was admitted to a psychiatric unit because of amnesia and hallucinations at the age of 51 years. $^{2}$ Deoxyribonucleic acid was extracted from a histological section of Auguste Deter's 


\section{香港首個研究比較家族性阿爾茨海默病患者與 經生物標誌物證實的晚發性阿爾茨海默病患者 \\ 佘日峰、朱亮榮、李瑞貞、陳安琪}

引言：香港的家族性阿爾茨海默病患者越來越多。本研究旨在報告這 些患者的臨床特徵, 並與經生物標誌物證實的晚發性阿爾茨海默病的 患者進行比較。

方法：1998年1月至2016年12月期間, 所有到瑪麗醫院記憶診所就診 的具症狀的家族性阿爾茨海默病患者均參與這研究。我們收集患者的 臨床特徵、基線迷你精神狀態檢查（MMSE）評分, 以及呈現認知症 狀或非典型臨床特徵的資料。將他們的臨床特徵與以下兩組患者進行 比較：12例經腦脊髓液生物標誌物證實的晚發性阿爾茨海默病患者,

以及 14 例正常澱粉樣蛋白載體匹垚堡複合物 B成像的晚發性阿爾茨海 默病患者。

結果：3個家庭共 8 名患者患有家族性阿爾茨海默病, 他們的平均（標 準差）發病年齡為48.4（7.7）歲，MMSE評分7.9（9.2）。與晚發 性阿爾茨海默病患者相比, 具有家族性阿爾茨海默病患者的發病年齡 和出現症狀均較早（兩者 $\mathrm{P}<0.001$ ），亦較遲接受正確診斷（中位數 7.5 年, 四分位數 5.3-14.5年, 比中位數 2 年, 四分位數 $1.0-3.3$ 年; $\mathrm{P}<0.001)$ 。患有家族性疾病的患者比晚發性阿爾茨海默病的患者的 MMSE評分較低（平均值士標準差， $7.9 \pm 9.2$ 比 $17.6 \pm 7.2 ; \mathrm{P}=0.01$ ) 他們出現妄想的情況較少、較少煩躁和較少易激惹（0\%比 $41.7 \%$ 、 $0 \%$ 比 $50 \%$ 和 $0 \%$ 比 $52.4 \% ; \mathrm{P}=0.04 、 0.01$ 和 $0.01 ）$; 另外也較少出現健忘 症 ( $75 \%$ 比 $100 \% ; \mathrm{P}=0.05$ )

結論：家族性阿爾茨海默病患者與晚發性阿爾茨海默病患者的臨床特 徵不同, 診斷有延遲。有必要提高公眾對家族性阿爾茨海默病的認 識。
Diagnosis of FAD is clinically important for the affected family. Genetic counselling may be offered to potential asymptomatic carriers if desired, as they may benefit from prenatal diagnosis and planning of personal affairs. ${ }^{4}$ Identification of asymptomatic carriers can also identify potential candidates for future drug trials of disease-modifying agents. With respect to preventive therapies, two clinical trialsthe DIAN-TU (Dominantly Inherited Alzheimer Network Trial Unit) and API (Alzheimer's Prevention Initiative)-are ongoing to test the efficacy of passive immunotherapy among normal or mildly symptomatic FAD mutation carriers. ${ }^{5,6}$ Thus, it is important to enhance local doctors' knowledge of FAD.

The objectives of this study were to report the clinical features of the first case series of Chinese FAD patients in Hong Kong, and to compare their clinical features with those of biomarker-confirmed sporadic LOAD patients. We hypothesised that patients with FAD had more atypical clinical features, and that this could contribute to a delay in correct diagnosis.

\section{Methods}

\section{Patients with familial Alzheimer's disease}

This was a retrospective case series of FAD patients diagnosed between January 1998 and December 2016 in the memory clinic of Queen Mary Hospital, Hong Kong. The FAD patients were identified by reviewing the case records of all patients diagnosed with EOAD during the study period. The study was performed in accordance with the principles outlined in the Declaration of Helsinki. All symptomatic FAD patients with confirmed mutations in PSEN1 or APP genes were included. To date, no FAD family with PSEN2 has been identified in Hong Kong. All these patients are pure Chinese. Detailed histories were obtained from primary caregivers. All patients underwent a physical examination, laboratory blood tests (including vitamin $\mathrm{B}_{12}$, folic acid, and thyroid function), computed tomography (CT) or magnetic resonance imaging (MRI) of the brain, and completed the Cantonese version of MiniMental State Examination (MMSE). ${ }^{7}$ These patients fulfilled the National Institute of Neurological and Communicative Disorders and Stroke and the Alzheimer's Disease and Related Disorders Association (NINCDS-ADRDA) diagnostic criteria of AD. ${ }^{8}$ In this study, AOO was defined as the age at first appearance of symptoms that interfered with social or occupational functioning. Age of correct diagnosis (AOCD) was defined as the age at which diagnosis of FAD was confirmed with genetic mutation. Duration of symptoms was defined as the difference between AOO and AOCD in years. Initial presenting cognitive symptoms and behavioural and psychological symptoms of 
dementia (BPSD) according to the Neuropsychiatric Inventory (NPI) were specifically collected from primary caregivers and were immediately recorded in the medical records. ${ }^{9}$ Of note, BPSD-including delusions, hallucinations, agitation, dysphoria, anxiety, euphoria, apathy, disinhibition, irritability, and aberrant motor behaviour-were recorded as binary variables (ie present or absent) as not all NPI scores could be retrieved. ${ }^{9}$ Authors (SYF and LSC), who were blinded to the hypothesis, retrieved the information related to initial presenting cognitive symptoms and BPSD.

\section{Selection of patients}

In summary, three families among whom eight patients were affected were included in this case series. Two families have been reported previously. ${ }^{10,11}$ For reference purposes, there were 18 patients with EOAD and no positive family history during the study period.

\section{Two patients with familial Alzheimer's disease}

This family has not been reported in detail previously. The family was referred to our memory clinic more than 10 years ago (Fig). The first case (II3; patient No. 5) was a 52-year-old woman who complained of progressive short-term memory impairment with impaired daily function, occupational performance, and management of personal finances. Her father (I1) and eldest brother (II1) had been diagnosed with dementia at around 50 years of age by doctors in China. As a result of these symptoms, her husband had divorced her, and she received care from her friend. Single-photon emission CT of the brain showed bilateral hypoperfusion over the frontal and temporoparietal lobes. She consented to genetic testing and gene sequencing for known FAD mutations, which was subsequently performed by The Tanz Centre for Research in Neurodegenerative Diseases, University of Toronto. A heterozygous missense mutation p.His163Arg in the PSEN1 gene was detected. She received rivastigmine treatment. Five years later, because of her poor drug compliance and impaired ability to carry out cooking and housework, arrangements were made for her to live in an elderly care home. Another patient (II4; patient No. 4) was her 46-year-old brother who was diagnosed with dementia by another hospital. He also consented to have genetic testing. The same heterozygous missense mutation was found.

\section{Late-onset Alzheimer's disease with biomarker confirmation}

Late-onset AD is defined as AD with AOO that occurs at or after the age of 65 years. During the study period, 12 patients with LOAD underwent cerebrospinal fluid (CSF) examination that revealed an AD pattern

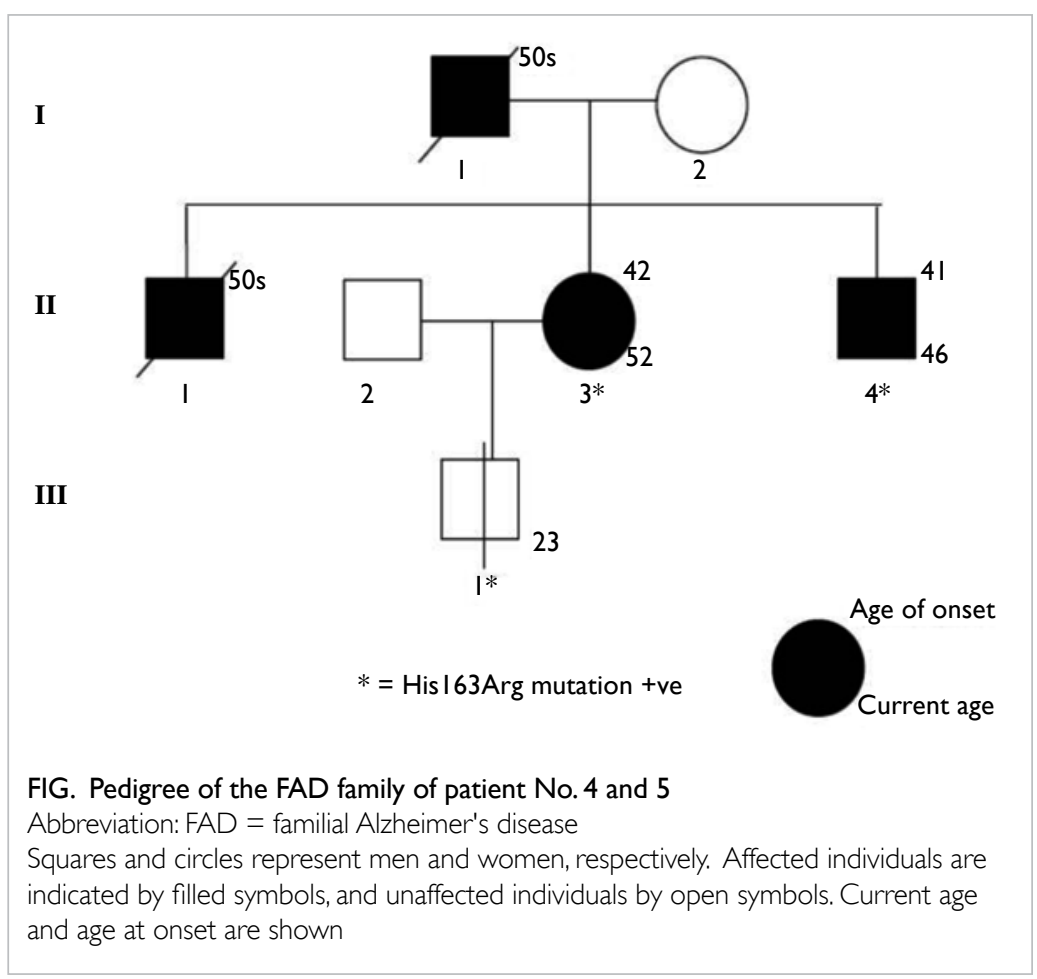

of CSF biomarkers (ie low amyloid-beta [A $\beta 42]$, and elevated total tau and phosphorylated tau [pTau]) within 1 month of clinical assessment. ${ }^{12}$ In addition, 14 patients with LOAD underwent ${ }^{11} \mathrm{C}$-Pittsburgh compound B (PIB) and ${ }^{18} \mathrm{~F}$-2-fluoro-2-deoxy-dglucose (FDG) positron emission tomography (PET) within 3 months of clinical assessment. Bilateral temporoparietal hypometabolism was evident on ${ }^{18} \mathrm{FDG}$ PET and positive amyloid loading on ${ }^{11} \mathrm{C}$-PIB (ie binding occurred in more than one cortical brain region: frontal, parietal, temporal, or occipital). ${ }^{13}$ Clinically, these patients also fulfilled the NINCDSADRDA criteria for AD. These patients had no history of stroke and their CT or MRI brain showed no evidence of infarcts or extensive white matter changes. For these 26 patients with LOAD, similar clinical information including basic demographics, AOO, AOCD (based on the availability of biomarkers' results), disease duration, Cantonese version of MMSE, initial presenting cortical symptoms, and BPSD was collected. For reference purposes, there were 2480 patients with LOAD without CSF biomarkers or FDG and PIB-PET examination during the same period of time.

\section{Statistical analysis}

Parametric variables are expressed as mean \pm standard deviation (SD). Non-parametric variables are expressed as median with interquartile range (IQR). Chi squared test or Fisher's exact test were 
used to compare categorical variables. Independent sample $t$ test or Mann-Whitney $U$ test was used to compare continuous variables when appropriate. Statistical significance was inferred by a twotailed $\mathrm{P}$ value of $<0.05$. All statistical analyses were performed using the SPSS (Windows version 18.0; SPSS Inc, Chicago [IL], US).

\section{Results}

\section{Case series of familial Alzheimer's disease}

There were three affected families with eight affected patients. Their clinical features are summarised in Table 1. The mean ( \pm SD) AOO and MMSE score were $48.4 \pm 7.7$ years and $7.9 \pm 9.2$, respectively. The mean duration of symptoms before genetic diagnosis was $10.1 \pm 7.1$ years. Patients 1 and 3 were initially misdiagnosed with depression and Parkinson's disease with dementia, respectively. The three most common presenting cognitive symptoms were amnesia (75\%), disorientation (63\%), and anomia (38\%).

\section{Comparison with late-onset Alzheimer's disease}

The comparison of demographics between FAD and LOAD patients is summarised in Table 2. The AOO and AOCD were much earlier for FAD than LOAD patients $(48.4 \pm 7.7$ vs $77.9 \pm 6.7$ years and $57.9 \pm$ 8.2 vs $80.7 \pm 6.2$ years; both $\mathrm{P}<0.001)$. The duration of symptoms was much longer for FAD patients than LOAD patients (median [IQR]: 7.5 [5.3-14.5] vs 2.0 [1.0-3.3] years; $\mathrm{P}<0.001)$. Patients with FAD had a lower presenting MMSE score than those with $\operatorname{LOAD}(7.9 \pm 9.2$ vs $17.6 \pm 7.2$; $\mathrm{P}=0.01)$. More patients with FAD had been educated to secondary level or above than LOAD patients $(\mathrm{P}=0.001)$.

The comparison of cognitive symptoms and BPSD between FAD and LOAD patients is summarised in Tables 3 and 4, respectively. There

TABLE I. A summary of all FAD patients attending the memory clinic of Queen Mary Hospital from January 1998 and December 2016

\begin{tabular}{|c|c|c|c|c|c|c|c|c|c|}
\hline $\begin{array}{l}\text { Patient } \\
\text { No. }\end{array}$ & $\begin{array}{c}\text { AOO } \\
\text { (years) }\end{array}$ & $\begin{array}{l}\text { Age of } \\
\text { diagnosis } \\
\text { of FAD } \\
\text { (years) }\end{array}$ & Sex & $\begin{array}{c}\text { Education } \\
\text { level }\end{array}$ & $\begin{array}{l}\text { Presenting } \\
\text { MMSE } \\
\text { score }\end{array}$ & Mutation & $\begin{array}{l}\text { Initial cognitive } \\
\text { symptoms }\end{array}$ & $\begin{array}{l}\text { Atypical clinical } \\
\text { features }\end{array}$ & $\begin{array}{l}\text { Neuroimaging } \\
\text { findings }\end{array}$ \\
\hline 1 & 40 & 48 & Female & Tertiary & 18 & $\begin{array}{l}A P P \\
\text { p.Val717lle }\end{array}$ & $\begin{array}{l}\text { Amnesia, depression, } \\
\text { impairment of } \\
\text { judgement, anomia, } \\
\text { acalculia, impairment in } \\
\text { handling banking }\end{array}$ & $\begin{array}{l}\text { Initially } \\
\text { misdiagnosed as } \\
\text { depression }\end{array}$ & $\begin{array}{l}\text { MRI brain: bilateral } \\
\text { hippocampal atrophy; } \\
\text { SPECT brain: } \\
\text { hypoperfusion over the } \\
\text { left temporoparietal } \\
\text { lobes and right parietal } \\
\text { lobes }\end{array}$ \\
\hline 2 & 50 & 66 & Female & Illiterate & 14 & $\begin{array}{l}A P P \\
\text { p.Val717lle }\end{array}$ & $\begin{array}{l}\text { Anomia, apathy, spatial } \\
\text { disorientation }\end{array}$ & Seizure & $\begin{array}{l}\text { CT brain with medial } \\
\text { temporal lobe atrophy; } \\
\text { SPECT: bilateral } \\
\text { hypoperfusion over } \\
\text { bilateral frontal and } \\
\text { temporoparietal lobes }\end{array}$ \\
\hline 3 & 58 & 62 & Male & Secondary & 5 & $\begin{array}{l}\text { APP } \\
\text { p.Val717lle }\end{array}$ & $\begin{array}{l}\text { Amnesia with spatial } \\
\text { disorientation, auditory } \\
\text { hallucination and } \\
\text { parkinsonism }\end{array}$ & $\begin{array}{l}\text { Initially diagnosed } \\
\text { as Parkinson's } \\
\text { disease with } \\
\text { dementia }\end{array}$ & $\begin{array}{l}\text { CT brain: left thalamic } \\
\text { infarct }\end{array}$ \\
\hline 4 & 41 & 46 & Male & Secondary & 23 & $\begin{array}{l}\text { PSEN1 } \\
\text { p.His163Arg }\end{array}$ & Amnesia & NA & NA \\
\hline 5 & 42 & 52 & Female & Secondary & 0 & $\begin{array}{l}\text { PSEN1 } \\
\text { p.His163Arg }\end{array}$ & Amnesia & NA & $\begin{array}{l}\text { SPECT brain: bilateral } \\
\text { hypoperfusion over } \\
\text { the frontal and } \\
\text { temporoparietal lobes }\end{array}$ \\
\hline 6 & 51 & 58 & Male & Secondary & 3 & $\begin{array}{l}\text { PSEN1 } \\
\text { p.Phe386lle }\end{array}$ & $\begin{array}{l}\text { Amnesia, disorientation, } \\
\text { apathy, dysexecutive } \\
\text { syndrome }\end{array}$ & NA & $\begin{array}{l}\text { MRI brain: bilateral } \\
\text { hippocampal atrophy }\end{array}$ \\
\hline 7 & 60 & 66 & Male & Secondary & 0 & $\begin{array}{l}\text { PSEN1 } \\
\text { p.Phe386lle }\end{array}$ & $\begin{array}{l}\text { Amnesia, disorientation, } \\
\text { apraxia }\end{array}$ & NA & $\begin{array}{l}\text { MRI brain: bilateral } \\
\text { hippocampal atrophy }\end{array}$ \\
\hline 8 & 45 & 65 & Female & Secondary & 0 & $\begin{array}{l}\text { PSEN1 } \\
\text { p.Phe386lle }\end{array}$ & $\begin{array}{l}\text { Amnesia, disorientation, } \\
\text { anomia, prosopagnosia, } \\
\text { dysexecutive syndrome, } \\
\text { anxiety }\end{array}$ & Seizure & $\begin{array}{l}\text { CT brain: severe } \\
\text { medial temporal lobe } \\
\text { atrophy }\end{array}$ \\
\hline
\end{tabular}

Abbreviations: $\mathrm{AOO}=$ age of onset; $\mathrm{APP}=$ amyloid precursor protein gene; $\mathrm{CT}=$ computed tomography; FAD = familial Alzheimer's disease; MMSE = MiniMental State Examination; MRI = magnetic resonance imaging; NA = not available; PSENI = presenilin I gene; SPECT = single-photon emission computed tomography 
TABLE 2. Comparison of clinical features between FAD and sporadic LOAD

\begin{tabular}{|c|c|c|c|}
\hline \multirow[t]{2}{*}{ Characteristic/clinical feature } & \multicolumn{2}{|c|}{ Data* $^{*}$} & \multirow[t]{2}{*}{$P$ value } \\
\hline & FAD $(n=8)$ & Sporadic LOAD ( $n=26)$ & \\
\hline Age of onset (years) & $48.4 \pm 7.7$ & $77.9 \pm 6.7$ & $<0.001 \dagger$ \\
\hline Age of correct diagnosis (years) & $57.9 \pm 8.2$ & $80.7 \pm 6.2$ & $<0.001 \dagger$ \\
\hline Duration of symptoms (years) & $7.5(5.3-14.5)$ & $2.0(1.0-3.3)$ & $<0.001 \ddagger$ \\
\hline Presenting MMSE score & $7.9 \pm 9.2$ & $17.6 \pm 7.2$ & $0.01 \dagger$ \\
\hline \multicolumn{4}{|l|}{ Education level } \\
\hline Illiterate & $1(12.5)$ & $19(73.1)$ & $0.001 \S$ \\
\hline Primary & $0(0)$ & $3(11.5)$ & \\
\hline Secondary & $6(75)$ & $2(7.7)$ & \\
\hline Tertiary & $1(12.5)$ & $2(7.7)$ & \\
\hline
\end{tabular}

Abbreviations: FAD = familial Alzheimer's disease; LOAD = late-onset Alzheimer's disease; MMSE = Mini-Mental State Examination

* Data are shown as mean \pm standard deviation, median (interquartile range), or No. (\%)

$\dagger t$ Test

‡ Mann-Whitney $U$ test

$\S$ Chi squared test

TABLE 3. Comparison of cognitive symptoms between FAD and sporadic LOAD

\begin{tabular}{|c|c|c|c|}
\hline \multirow[t]{2}{*}{ Cognitive symptom } & \multicolumn{2}{|c|}{ No. (\%) of patients } & \multirow[t]{2}{*}{ P value* } \\
\hline & FAD $(n=8)$ & Sporadic LOAD $(n=26)$ & \\
\hline Amnesia & $6(75.0)$ & $26(100)$ & 0.05 \\
\hline Agnosia & $1(12.5)$ & $5(19.2)$ & 1.0 \\
\hline Apraxia & $1(12.5)$ & $6(23.1)$ & 1.0 \\
\hline Anomia & $3(37.5)$ & $6(23.1)$ & 0.65 \\
\hline Dyslexia & $0(0)$ & $0(0)$ & - \\
\hline Dysgraphia & $0(0)$ & $1(3.8)$ & 1.0 \\
\hline Dysexecutive syndrome & $2(25.0)$ & $9(34.6)$ & 1.0 \\
\hline Depression & $1(12.5)$ & $2(7.7)$ & 1.0 \\
\hline Parkinsonism & $1(12.5)$ & $0(0)$ & 0.24 \\
\hline
\end{tabular}

Abbreviations: FAD = familial Alzheimer's disease; $L O A D=$ late-onset Alzheimer's disease

* Fisher's exact test

TABLE 4. Comparison of BPSD between FAD and sporadic LOAD

\begin{tabular}{|c|c|c|c|}
\hline \multirow[t]{2}{*}{ BPSD } & \multicolumn{2}{|c|}{ No. $(\%)$ of patients } & \multirow[t]{2}{*}{$P$ value } \\
\hline & FAD $(n=8)$ & Sporadic LOAD $(n=24)^{*}$ & \\
\hline Delusion & $0(0)$ & $10(41.7)$ & 0.04 \\
\hline Hallucination & $1(12.5)$ & $3(12.5)$ & 1.0 \\
\hline Agitation & $0(0)$ & $9(37.5)$ & 0.07 \\
\hline Dysphoria & $0(0)$ & $12(50.0)$ & 0.01 \\
\hline Anxiety & $1(12.5)$ & $5(20.8)$ & 1.0 \\
\hline Euphoria & $0(0)$ & $2(8.3)$ & 1.0 \\
\hline Apathy & $2(25.0)$ & $10(41.7)$ & 0.68 \\
\hline Disinhibition & $0(0)$ & $1(4.2)$ & 1.0 \\
\hline Irritability & $0(0)$ & $13(54.2)$ & 0.01 \\
\hline Aberrant motor behaviour & $0(0)$ & $2(8.3)$ & 1.0 \\
\hline
\end{tabular}


was a trend wherein patients with FAD were less likely to present with amnesia ( $75 \%$ vs $100 \%$; $\mathrm{P}=0.05)$ than those with LOAD although it was still their main presenting cognitive symptom. Patients with LOAD more commonly presented with delusion, dysphoria, and irritability than FAD patients $(0 \%$ vs $41.7 \%, 0 \%$ vs $50 \%$, and $0 \%$ vs $54.2 \%$ respectively; $\mathrm{P}=0.04,0.01$, and 0.01 , respectively).

\section{Discussion}

In this case series, there was significant delay in making a correct diagnosis of FAD among patients who presented at a late stage of dementia compared with patients with LOAD. Patients with LOAD more often presented with BPSD such as delusion, dysphoria, and irritability.

There are several factors that contribute to the delay in diagnosis and thus the late presentation of FAD patients to the memory clinic. First, the availability of genetic tests is not well known to local doctors. Currently doctors in public hospitals can consult with a clinical biochemist if they encounter a family with at least two generations having EOAD. Genetic tests can be arranged for PSEN1, APP, and PSEN2 sequentially. Second, patients with FAD may have atypical clinical features. In our case series, two patients were initially misdiagnosed as depression and Parkinson's disease with dementia. Our previous systematic review indicated that patients with FAD and PSEN1 mutations can present with parkinsonism, seizures, spastic paraparesis, myoclonus, and cerebellar dysfunction. Chinese FAD patients with an $A P P$ mutation can present with atypical phenotypes with a prominent psychiatric manifestation, behavioural and language variants. ${ }^{1}$ Patients with FAD with a PSEN2 mutation can present with a later AOO even within the same family. ${ }^{1}$ It is important for local doctors to be aware of the possibility of these atypical clinical features in their EOAD patients, especially if there is a positive family history of EOAD. Third, since FAD is not treatable, genetic testing may not be considered. Nonetheless, genetic counselling is important for patients with FAD. Asymptomatic carriers are also potentially valuable for future clinical trials. ${ }^{4-6}$

In terms of cognitive symptoms, patients with FAD tended to present slightly less frequently with amnesia than those with LOAD, although amnesia remained their main presenting cognitive symptom. This is in agreement with previous studies that reported EOAD patients to have more prominent frontoparietal dysfunction than medial temporal dysfunction. ${ }^{3,14,15}$ Our study also identified that LOAD patients have more positive symptoms of BPSD including delusions and irritability. Table 5 summarises the differences in BPSD between FAD and LOAD patients in our study and in other reported studies between EOAD and LOAD patients. ${ }^{16-18}$

There are several potential reasons for the different clinical features between FAD and LOAD patients. First, patients with FAD have a genetic mutation that increases the production of $A \beta 42$ from early on in life. This explains the much earlier AOO. ${ }^{19}$ Second, pathological studies of the brain of FAD patients seldom noted non-AD pathological changes. On the contrary, $42 \%$ of LOAD patients exhibited at least one other concurrent clinicopathological diagnosis such as vascular dementia, dementia with Lewy bodies, hippocampal sclerosis, or Pick's disease. ${ }^{20}$ Third, amyloid plaques in LOAD patients are mostly compact or diffuse while those in FAD

TABLE 5. A comparison between our study findings on BPSD with other studies comparing EOAD and LOAD patients ${ }^{16-18}$

\begin{tabular}{|c|c|c|}
\hline Study & Sample size & Key findings (all statistically significant) \\
\hline Toyota et al ${ }^{18}$ & $\begin{array}{l}\text { EOAD }(n=46) ; \text { LOAD }(n=261) \\
\text { Diagnosis based on clinical criteria and SPECT }\end{array}$ & $\begin{array}{l}\text { LOAD patients more commonly manifested delusion }(50.6 \% \text { vs } 13.0 \%) \text {, } \\
\text { hallucination }(22.6 \% \text { vs } 4.3 \%) \text {, agitation ( } 44.8 \% \text { vs } 28.3 \%) \text {, disinhibition } \\
\text { (16.5\% vs } 4.3 \%) \text {, and aberrant motor behaviour ( } 43.7 \% \text { vs } 26.1 \%) \text { than } \\
\text { EOAD patients }\end{array}$ \\
\hline Park et al ${ }^{17}$ & $\begin{array}{l}\text { EOAD }(n=435) \text {; LOAD }(n=435) \\
\text { Diagnosis based on clinical criteria; matching was } \\
\text { performed by propensity score }\end{array}$ & $\begin{array}{l}\text { LOAD patients more commonly manifested delusions }(26.2 \% \text { vs } 19.1 \%) \\
\text { and hallucinations }(14.6 \% \text { vs } 10.1 \%) \text { than EOAD patients. EOAD patients } \\
\text { manifested more apathy }(59.4 \% \text { vs } 46.2 \%) \text { than LOAD patients }\end{array}$ \\
\hline Mushtaq et $a^{16}$ & $\begin{array}{l}\text { EOAD }(n=40) ; \text { LOAD }(n=40) \\
\text { Diagnosis based on clinical criteria; two groups } \\
\text { were matched for education, gender, MMSE } \\
\text { score, disease duration and severity }\end{array}$ & $\begin{array}{l}\text { LOAD patients had higher symptom severity scores (NPI) for delusions } \\
(1.37 \pm 0.49 \text { vs } 0.94 \pm 0.42) \text {, agitation }(2 \pm 0 \text { vs } 1.2 \pm 0.4) \text {, anxiety }(3.03 \\
\pm 0.91 \text { vs } 2.57 \pm 0.5) \text {, disinhibition }(1 \pm 0 \text { vs } 0.12 \pm 0.33) \text {, and night- } \\
\text { time behavioural disturbances }(2.47 \pm 0.71 \text { vs } 1.35 \pm 0.48) \text { than EOAD } \\
\text { patients }\end{array}$ \\
\hline Present study & $\begin{array}{l}\text { FAD }(n=8) ; \text { LOAD }(n=26) \\
\text { Diagnosis based on genetic mutation confirmation, } \\
\text { CSF biomarkers, and PIB-PET scan }\end{array}$ & $\begin{array}{l}\text { LOAD patients more commonly presented with delusion ( } 41.7 \% \text { vs } 0 \%) \text {, } \\
\text { dysphoria ( } 50 \% \text { vs } 0 \%) \text {, and irritability }(54.2 \% \text { vs } 0 \%)\end{array}$ \\
\hline
\end{tabular}

Abbreviations: BPSD = behavioural and psychological symptoms of dementia; CSF = cerebrospinal fluid; EOAD = early-onset Alzheimer's disease; FAD = familial Alzheimer's disease; LOAD = late-onset Alzheimer's disease; MMSE = Mini-Mental State Examination; NPI = neuropsychiatric inventory score; PIBPET = Pittsburgh compound B positron emission tomography; SPECT = single-photon emission computed tomography 
patients exhibit various morphologies associated with the specific PSEN mutation. ${ }^{20}$ Fourth, PSEN 1 and 2 form the catalytic subunit of $\gamma$-secretase and apart from amyloid beta precursor protein, there are over 90 other substrates upon which $\gamma$-secretase can act; this may explain the wide range of phenotypes for FAD patients with PSEN mutations. ${ }^{20}$

The strength of the study is that the diagnoses of FAD and LOAD were supported by genetic analyses and imaging/CSF biomarkers, respectively. There are a number of limitations in our study. First, FAD accounted for only a minority of EOAD cases and thus our results may not be generalised to sporadic EOAD patients. Second, the severity of BPSD could not be compared. In future, NPI scores should be compared. In addition, detailed neuropsychological tests were not performed because of the busy clinical setting in our memory clinic. Third, the sample size is small and our results must be treated as preliminary. Fourth, the presence or absence of symptoms depends on the recall of primary caregivers and is subject to recall bias. Fifth, apolipoprotein E status is an important genetic contributor to LOAD but it was not checked in all LOAD patients in this study. ${ }^{4}$ Despite these limitations, this is the first local study in Hong Kong to compare Chinese FAD and LOAD patients.

In summary, there are differences in clinical features between patients with FAD, who receive a correct diagnosis much later, and patients with LOAD. Promotion of public awareness of FAD in Hong Kong is much needed to help those families that are affected but not yet identified.

\section{Declaration}

All authors have disclosed no conflicts of interest.

\section{References}

1. Shea YF, Chu LW, Chan AO, Ha J, Li Y, Song YQ. A systematic review of familial Alzheimer's disease: differences in presentation of clinical features among three mutated genes and potential ethnic differences. J Formos Med Assoc 2016;115:67-75.

2. Müller U, Winter P, Graeber MB. A presenilin 1 mutation in the first case of Alzheimer's disease. Lancet Neurol 2013;12:129-30.

3. Tellechea P, Pujol N, Esteve-Belloch P, et al. Early- and lateonset Alzheimer disease: are they the same entity [in English, Spanish]? Neurologia 2015;pii:S0213-4853(15)00210-8.

4. Bird TD. Genetic aspects of Alzheimer disease. Genet Med 2008;10:231-9.

5. Bateman RJ, Benzinger TL, Berry S, et al. The DIAN-TU Next Generation Alzheimer's prevention trial: adaptive design and disease progression model. Alzheimers Dement 2017;13:8-19.
6. Reiman EM, Langbaum JB, Fleisher AS, et al. Alzheimer's Prevention Initiative: a plan to accelerate the evaluation of presymptomatic treatments. J Alzheimers Dis 2011;26 Suppl 3:321-9.

7. Chiu FK, Lee HC, Chung WS, Kwong PK. Reliability and validity of the Cantonese version of the Mini-Mental State Examination-A preliminary study. J Hong Kong Coll Psychiatr 1994;4:25S-28S.

8. McKhann GM, Knopman DS, Chertkow H, et al. The diagnosis of dementia due to Alzheimer's disease: recommendations from the National Institute on AgingAlzheimer's Association workgroups on diagnostic guidelines for Alzheimer's disease. Alzheimers Dement 2011;7:263-9.

9. Cummings JL, Mega M, Gray K, Rosenberg-Thompson S, Carusi DA, Gornbein J. The Neuropsychiatric Inventory: comprehensive assessment of psychopathology in dementia. Neurology 1994;44:2308-14.

10. Shea YF, Chan AO, Chu LW, et al. Novel presenilin 1 mutation (p.F386I) in a Chinese family with early-onset Alzheimer's disease. Neurobiol Aging 2017;50:168.e9-11.

11. Shea YF, Chu LW, Chan AO, Kwan JS. Delayed diagnosis of an old Chinese woman with familial Alzheimer's disease. J Formos Med Assoc 2015;114:1020-1.

12. Shea YF, Chu LW, Zhou L, et al. Cerebrospinal fluid biomarkers of Alzheimer's disease in Chinese patients: a pilot study. Am J Alzheimers Dis Other Demen 2013;28:769-75.

13. Shea YF, Ha J, Lee SC, Chu LW. Impact of (18)FDG PET and (11)C-PIB PET brain imaging on the diagnosis of Alzheimer's disease and other dementias in a regional memory clinic in Hong Kong. Hong Kong Med J 2016;22:327-33.

14. Cavedo E, Pievani M, Boccardi M, et al. Medial temporal atrophy in early and late-onset Alzheimer's disease. Neurobiol Aging 2014;35:2004-12.

15. Kaiser NC, Melrose RJ, Liu C, et al. Neuropsychological and neuroimaging markers in early versus late-onset Alzheimer's disease. Am J Alzheimers Dis Other Demen 2012;27:520-9.

16. Mushtaq R, Pinto C, Tarfarosh SF, et al. A comparison of the Behavioral and Psychological Symptoms of Dementia (BPSD) in early-onset and late-onset Alzheimer's disease-a study from South East Asia (Kashmir, India). Cureus 2016;8:e625.

17. Park HK, Choi SH, Park SA, et al. Cognitive profiles and neuropsychiatric symptoms in Korean earlyonset Alzheimer's disease patients: a CREDOS study. J Alzheimers Dis 2015;44:661-73.

18. Toyota Y, Ikeda M, Shinagawa S, et al. Comparison of behavioral and psychological symptoms in early-onset and late-onset Alzheimer's disease. Int J Geriatr Psychiatry 2007;22:896-901.

19. Cacace R, Sleegers K, Van Broeckhoven C. Molecular genetics of early-onset Alzheimer's disease revisited. Alzheimers Dement 2016;12:733-48.

20. Roher AE, Maarouf CL, Kokjohn TA. Familial presenilin mutations and sporadic Alzheimer's disease pathology: is the assumption of biochemical equivalence justified? J Alzheimers Dis 2016;50:645-58. 